\title{
MODEL OF TRADITIONAL MARKET AS CULTURAL PRODUCT OUTLET AND TOURISM DESTINATION IN CURRENT ERA
}

\author{
Istijabatul ALIYAH (1) ${ }^{1,2^{*}}$, Galing YUDANA (D) ${ }^{1,2}$, Rara SUGIARTI (D) ${ }^{2}$ \\ ${ }^{1}$ Department of Regional and Urban Planning, Engineering Faculty, Sebelas Maret University, \\ Surakarta, Indonesia \\ ${ }^{2}$ Research and Development Centre of Tourism and Culture, Research and Community Service Institute \\ Sebelas Maret University, Surakarta, Indonesia
}

Received 30 October 2019; accepted 16 April 2020

\begin{abstract}
The phenomenon occurring along with traditional market development is the safety aspect, criminal activities, the low hospitality in serving buyers, the lack of honesty in trade, excessive price range in bargaining, and the lack of product information. This study aims to formulate model of traditional markets as cultural product outlet and tourism destination in the current era. It was a descriptive study with a qualitative approach. Its location is Pasar Klewer, Surakarta District with considering textile commodity specification of cultural production result of low-class economy communities with the scale of South-East Asia service. The study began with the explorations of potential, problems, effort and service of traditional markets, and government policy and commitment. Data were obtained through spatial and aspatial identification, site observation, in-depth interview, and document study. Sampling techniques were purposive and snowball sampling techniques. Furthermore, data analysis was carried out by using analytical methods, including 1) External and Internal Factors Analysis Summaries to analyze potential, problems, effort and service of traditional markets, and 2) Interactive Analysis to analyze the relevance of policy, commitment and effort carried out by traditional market actors. The result shows that traditional markets are one of tourism destination with historical values as outlets of community cultural products and populist economic spaces based on human source capabilities. The benefit of this study is directly received by market actors, policymakers of Surakarta Government, community and tourists, as well as academicians in scientific development in relation to cultural-art and tourism development based on the populist economy.
\end{abstract}

Keywords: traditional market, cultural product outlet, tourism destination, current era.

\section{Introduction}

Traditional markets are not merely places to buy and sell, but are considered as the conception of life and sociocultural interaction, as well as recreational facilities within the region and city (Aliyah et al., 2016). The development of traditional markets is accompanied by the increase of criminals, lack of hospitality in serving buyers, lack of honesty in trade, excessive price range in bargaining, and lack of product information. Traditional markets spatially have a humanist characteristic so that can build closeness and "familial" relationships between traders and buyers. The factor of spatial layout is able to influence traders' services in identifying consumers, and then being able to encourage them to re-shop in traditional markets. These friendly and familiar relationships between traders and buyers, become typical characteristics of traditional markets (Rahadi,
2012). According to Andriani and Ali (2013), the existence of traditional markets is underlied by social capitals, such as norms, belief, bargaining that can strengthen loyal networks of market visitors to keep shopping in traditional markets (Andriani \& Ali, 2013). In connection to the humanist characteristic of traditional markets, Rahadi (2012) reinforced that service quality and consumer identification factors play important roles in encouraging consumers to shop or re-shop in traditional markets.

In Dangdaemun, the Republic of Korea, traditional markets are reflected in modern styles with their orientation as commercial facilities. However, these markets substantially become part of the representations of trader organization and user social system, even are constructed as the social structure, which are gradually accumulated into the latent energy power (Kim et al., 2004). Likewise, in India, entrepreneurship aspiration and motivation of

${ }^{*}$ Corresponding author. E-mail: istijabatul@ft.uns.ac.id 
middle-class economy community become important aspects to achieve financial needs as both consumers and market users (Javalgia \& Grossman, 2016). In Bangkok, the frequence of consumers in re-visit traditional markets is determined by the significant relationship between consumers' attitudes toward prices, sellers' services, place quality, and buying and selling behaviours (Wongleedee, 2015). Meanwhile, in Denmark, the variable of placing urban facilities influence the movement of cetain activity. Distances from residence to the city center is a key factor affecting the accessibility to a number of facilities accommodating activities (N/ss \& Jensen, 2004). In line with N/ss and Jensen (2004), in a macro scope, Indonesian traditional markets within urban areas indicate that urban spatial planning or relocating traditional markets is able to change land use, road pattern, building movement or building types, and even distribution of circulation line (Ekomadyo, 2007). However, in a macro scope, Indonesian tranditional markets are similar to the ones in Bangkok reflected that service quality, the increase of trader numbers and consumer identification factors play important role to push the development and increase of shopping activities in traditional markets (Rahadi, 2012). Traditional markets are considered as part of the cultural products and urban public places, the place where people gather and construct their social relation (Ekomadyo, 2007). Moreover, some studies suggest that traditional markets become nodes of regionally exchanging goods and services, which then grow and develop generating many activities in the city (Sirait, 2006).

The problem faced by society, government, traders, and tourists is that traditional markets as one of tourism destinations and cultural outlets need an arrangement to create the safe and comfortable traditional markets with optimal services. It is reinforced by Aliyah, Setioko, and Pradoto (2016) who suggested the role of traditional markets in the city as one of main urban structure components, the gravity centers of the city, and the spaces of life conception and socio-cultural interactions (Aliyah et al., 2016). Besides, Aliyah et al. (2007b) also claimed that traditional markets are one of the tourism destinations with historical values as cultural product outlets and populist economy spaces based on human resource abilities (Aliyah et al., 2007b). Hence, this study is significant to create a fundamental in structuring and developing traditional markets. In this era, traditional markets faced problems from spatial and aspatial aspects as cultural product outlets to be able to adapt the current development or current era. The result is in terms of a model of traditional markets as cultural product outlets and tourism destinations in the current era. It is used to make traditional market development able to be conducted directionally and continually.

\section{Methods}

This study was a descriptive research with using qualitative approach. Location where this case study taken place was Surakarta District, considering that Surakarta District is the center of Javanese culture and has a specific distribution and number of traditional markets. It was exactly conducted in Pasar Klewer, Surakarta District with reference to textile commodity specifications of cultural-art product produced by the low-class economy community with South-East Asia service scale. The position of Surakarta District and Pasar Klewer was represented in the following Figure 1.

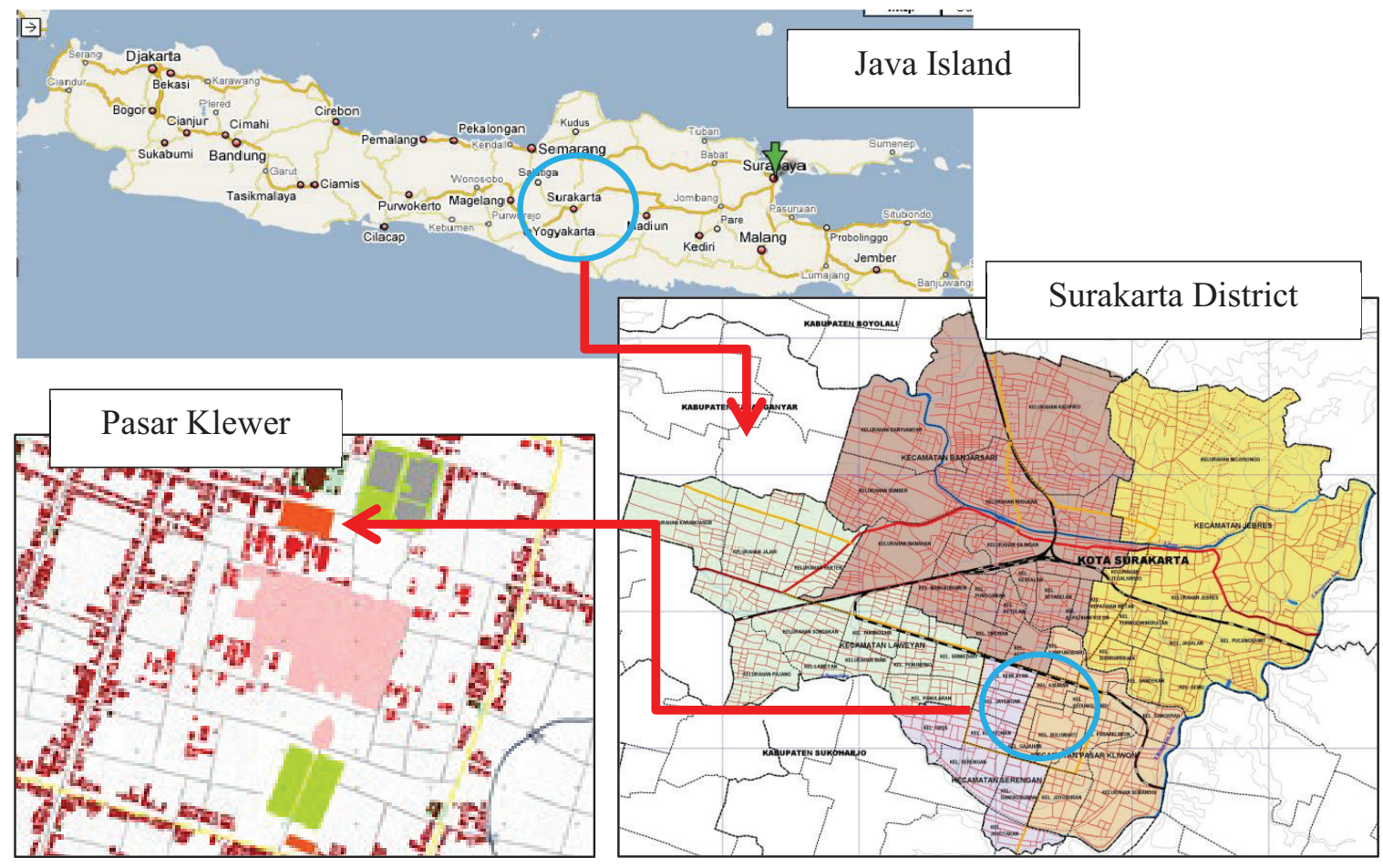

Figure 1. Position of research location, Surakarta district and Pasar Klewer in Javanese Island constellation, Indonesia 
It was stated with exploring traditional market potentials, problems, efforts and services; and government policies and commitments. Data were obtained through spatial and aspatial identifications, site observation, in-depth interview, and document study. Sampling techniques were purposive and snowball sampling techniques. Sample was chosen by some criteria that are 1) traders including registered permanent traders and impermanent traders, 2) visitors consisting of wholesale buyers, retail buyers, and tourists, 3) market manager in terms of market clerks, janitors, and security guards. Furthermore, data analysis was carried out by using analytical methods, including 1) External and Internal Factors Analysis Summaries to analyze potential, problems, effort and service of traditional markets. It was adopted from External Factors Analysis Summary \& Internal Factors Analysis Summary proposed by Wheelen and Hunger (2012) and Interactive Analysis suggested by Miles and Huberman (1984). Interactive analysis was to analyze the relevance of policy, commitment, and effort carried out by traditional market actors. It also viewed the relationship of each research process consisting of data collection, data display, data reduction, and verification/drawing conclusion (Miles \& Huberman, 1994).

The outcomes were the investigation on Existence of Traditional Market in City Center, Traditional Market Service Range as Urban Facility, Traditional Market Role as Cultural Product Outlet, and Tourism Destination in the current era. Based on these investigations, the study then conducted more comprehensive analysis to formulate traditional market model as cultural product outlet and cultural destination in the current era to support Surakarta Government decision and policy.

The benefit was directly received by market actors, policy makers of Surakarta government, community and tourists, as well academicians in scientific development related to the development of art-culture and tourism based on populist economy.

\section{Discussion}

\subsection{Existence of traditional market in city center}

Traditional markets are one of Javanese traditional city components. Surakarta District are built with three main basic urban components, namely kraton (the palace, located in the capital of the kingdom), mosque, and market. These componenets are the realization of aturan (rules), sujud manembah (prostration of worship), and ucap syukur (saying thanks to God), which become philosophical values held by a king in governing a country or kingdom. In this case, markets are the realization of ucap syukur concept.

The existence of traditional markets in Surakarta district has roles as urban structure components as well as populist-based trade facilities. Besides, traditional markets play as interactional spaces between market actors and cultural product displays of the local community. This is in line with Parmadhi who stated that fuctions of tradi- tional markets are not only for distributing, organizing product, determining values, price-making, but also for being meeting center, information exchange center, community center, even tourism package offered (Pamardhi, 1997). Besides, traditional markets function to suppress and to manage market actors involved as well as to become solutions in giving and providing various facilities (Abdullah, 2006). In relation to general function of markets, markets function as distributor, product organizer, value determiner, and price maker (Sunoko, 2002). Traditional markets in Asian countries are located in rural and urban areas (Hayami, 1987). In fact, the existence of traditional markets lies in social capitals in terms of norms, belief, and bargaining that can streghten loyal networks of market visitors to keep shopping in traditional markets (Bromley, 1987). Additionally, traditional markets have strategic roles in maintaining the structure of the development center. It is reflected by the ability of traditional markets in generating economic activities around market places (Alexander, 1987). Moreover, the relocation of markets is also able to change land use, road pattern, building movement and building pattern or building type that increasingly develop, and even distribution of circulation line (Karnajaya, 2002).

\subsection{Traditional market service range as urban facility}

Surakarta District as one of Javanese traditional cities, has traditional markets as economic facilities with the significant number compared to the area of Surakarta District. As shopping service centers, there are 43 units traditional markets spread in the area as much as $44.03 \mathrm{ha}$, in which if it is calculated in service ratio, there are some overlapping services on the spatial system and number of traditional markets in Surakarta District (Aliyah et al., 2017a). The classification of service scope can spatially be relected in the traditional market mapping in Surakarta District, as shown in the following Figure 2.

One of traditional markets existing in Surakarta District is Pasar Klewer. In the urban constellation, Pasar Klewer occupies a strategic position. It is located in the west of Kraton Kasunanan Surakarta Hadiningrat. Based on the data of service range, Pasar Klewer has international level service range with the product specification of textile commodities.

Pasar Klewer was built in 1968 and legitimated by the second President of the Republic of Indonesia, Soeharto. Surprisingly, Pasar Klewer is the biggest clothing wholesale in Central Java, considering that Surakarta District is the center of batik, which become the main commodity in Pasar Klewer. In 2000s, the name of Pasar Klewer become famous not only in regional scope but also in national and international scopes. Many consumers come from foreign countries to buy typical batik from Surakarta. Moreover, many foreign tourists and traders go shopping in a huge quantities or wholesale level. The increase number of 


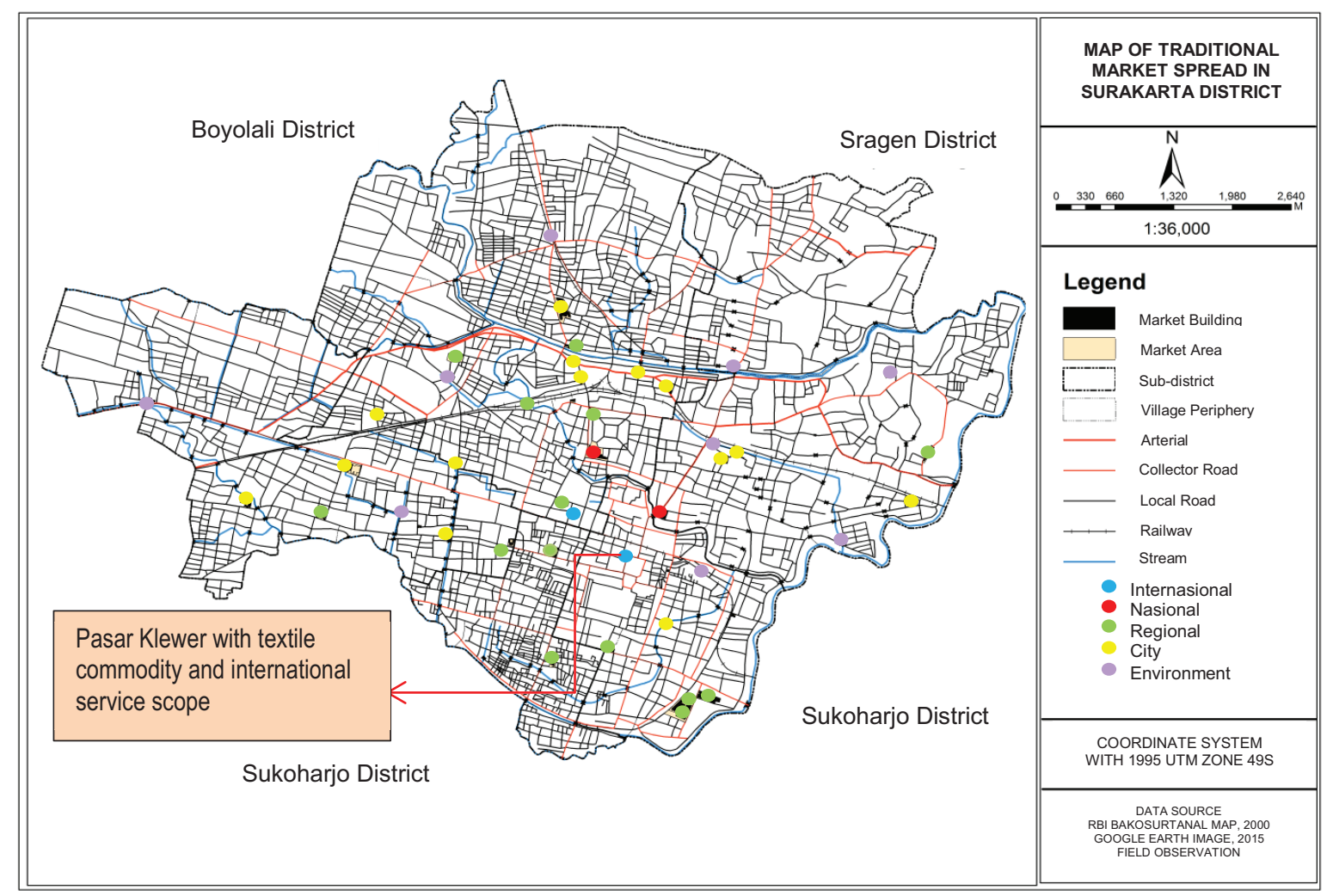

Figure 2. Scope of traditional markets in Surakarta district (Aliyah et al., 2017a)

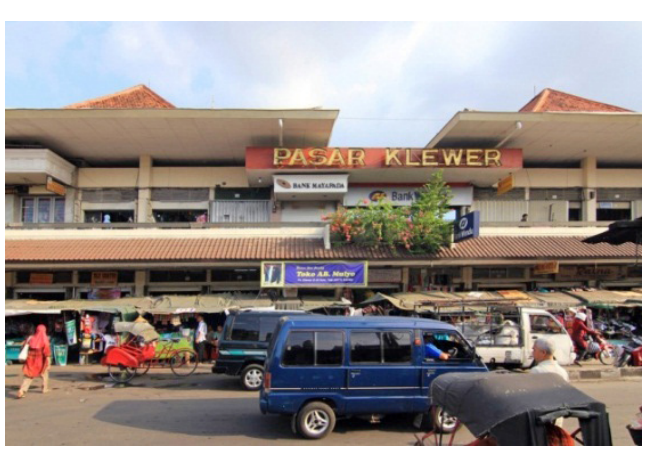

Pasar Klewer conditions before the fire

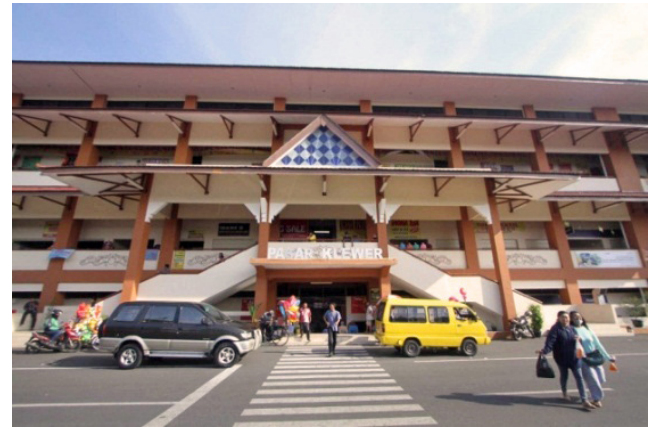

Pasar Klewer conditions after renovation

Figure 3. Pasar Klewer conditions (Kota Surakarta, March 22, 2018)

visitors in special days or holidays makes Pasar Klewer crowded and results in traffic jam along Jalan dr. Rajiman.

At the end of 2014, in December, there is a big event that is the first floor of Pasar Klewer is caught on fire due to short electric spark. Surakarta government then conducted revitalization of Pasar Klewer, started from April, 2015 and finished in the mid-2017, as shown in the following Figure 3. Physically, Pasar Klewer has different structure, but service scope and number of consumers are relatively stable.

The growth of traders and consumers in terms of buyers and distributors makes market capacity overload. Such condition makes markets decrease in the physical quality. The safety in economic context, different and differenciated economic offers, is jointly created and easy to remem- ber. Hence, the continues innovation is needed to serve consumer with various needs and smart demand. This can be done by three organization capacities, namely Connect, Energize, and Refresh (Sipe, 2016). Furthermore, service orientation from employees can partially mediate the relationship between service climate and service performance reported independently or reported by supervisors. Finally, it leads to employee service orientation and employee service carrier (Li \& Huang, 2017). The customer satisfaction is probably affected by service failure. Nevertheless, the most effective service recoevey to cope with service failure can be conducted by 1) Correcting All Problems; 2) Asking for Apologies; 3) Conducting Replacement; and 4) Giving Discounts (Wu et al., 2018). 


\subsection{Traditional market role as cultural product outlet}

Pasar Klewer provides various types of fabrics and clothing ranging from children's clothing, adults' clothing, elders' clothing, school uniforms, women shirts, and casual wears. Besides, there are also t-shirts, jackets, ties, cotton fabrics, and silks. The prominent commodity in Pasar Klewer is the existence of various types of batik, including hand written batik, stamp batik, kraton antique batik, and Solo pageant batik. Moreover, there are many types batik from Yogyakarta, Pekalongan, Banyumas, Madura, Betawi and other districts. In Pasar Klewer, there are also batik material for clothing, bedsheets, pillowcases, and accessories with batik pattern.

There are some attractive parts of Pasar Klewer that make visitors happy and re-shop in Pasar Klewer. The first is the price, which is relatively cheap. This condition probably happens because the majority of traders in Pasar Klewer also have garment industries. The second is traders' hospitality. In fact, there is a principle commited by traders, namely ora bati ora popo, ning bati paseduluran, which means there is no problem for not having profit, but the importance is establishing brotherhood. With reference to this principle, the relationship of sellers-buyers is not only the business relationship but also the familial one. This principle also probably makes the price cheap.

The effort of traditional market development is conducted by social mapping into some programs to improve social capitals, namely community development, employee recruitment plan, outsourcing plan, restoration of merchant forum, scheduled local community involvement forum, cooperation recovery, tourism development, and public rest room procurement (Putra and Rudito, 2014). Some studies have revealed that traditional markets become parts of the culture outlets. In India, entrepreneurship aspiration and motivation of middle-class economy community become the most important aspect to achieve the good financial needs as consumers and market actors (Pillai, 2013). In Bangkok, the reslationship between traditional markets and their consumers is closely related, and the frequency of consumers to revisit traditional markets is determined by the significant relationship between consumers' attitude towad price ranges, seller's service, place quality, and buying and selling behaviour (Duxbury et al., 2015). This is in line with Pillai (2013) who suggested that cultural mapping has an important role as a systematic approach to record and to provide the integrated description of cultural characters of a certain place, and how these characters can contribut to and continue planning sensitivity. Cultural mapping can explain how "sense of place" arises from the long symbiosis relationship between physical place, people as actors and livelihood (Pillai, 2013). Meanwhile, Duxbury et al. (2015) assumed that cultural mapping is practical, in which participatory planning and tool development that arise from the process of cultural mapping research have a close relationship with cultural mapping practice in professional context (Duxbury et al., 2015). However, Freitas (2016) undelined the differences between instrumental ulitarian approach, which is in line with the application of cultural intelligence, and integrated humanistic approach, which is in line with conceptual development and cultural mapping application. This knowledge has significant added value since the purpose of mapping focuses on the local speficity treatment, such as tourist attraction for demarcating local specificities (Freitas, 2016).

\subsection{Tourism destination in the current era}

Since lifestyle changes, such as people interest to shop and to look for recreation in the mall, traditional markets started to improve their qualities by providing cleaner and more comfortable facilities and merchandises. This also occurs in Pasar Klewer that market revitalization keeps being conducted to attract public interests and to give the optimal services to market visitors in terms of traders and tourists. Besides, government also proposes Regional Regulation to change the term of Pasar Tradisional (traditional market) into Pasar Rakyat (Folk Market), to avoid society's feeling about traditional markets' antiquity. The worst is the spread of discourse that who visit traditional market is merely for constructing image (Aliyah et al., 2017a). Hence, there is a need of the continuous expansion of marketing activities and the implementation of new marketing strategies in Marketing Strategy applied in cultural realization business practices (Dragicevic \& Tevsic, 2015). In relation to the complexity of commercial facilites as current tourist destination, a new concept related to the diversity and complexity of commercial block gentrification through the relationship beween young people, and Chinese commercial blocks through "youthification" lens, emerges (Ma et al., 2018).

\subsection{Traditional market model as cultural product outlet and tourism destination in the current era}

As an effort to create Traditional Markets as Cultural Outlet Products and Tourism Destinations in the Current Era, the formulation of traditional market model is used as the basic concept for traditional market development and structure. Based on the investigation on the growth of traders and consumers in terms of buyers and distributors; physical and non-physical condition; as well as safety and comfort in activities and transactions, a continues innovation is needed to fulfil consumers' need with various and smart demands. This has to be done by three organization capacities including Connect, Energize, and Refresh (Sipe, 2016). Moreover, service orientation and work atmosphere become an effective mediator from market actors in traditional markets. It is in line with $\mathrm{Li}$ and Huang (2017). Meanwhile, customer satisfaction is affected by service failure. To effectively recover the service due to failure is conducted by 1) immediately correcting the problem, 2) asking for forgiveness, 3) compensation, and 4) discount (Wu et al., 2018). Regarding this result, Culture Outlet and Tourism Acceleration Model abbreviated as COATAM is formulated and drawn in the diagram as the following Figure 4. This model consists of some inseparable components because each component 


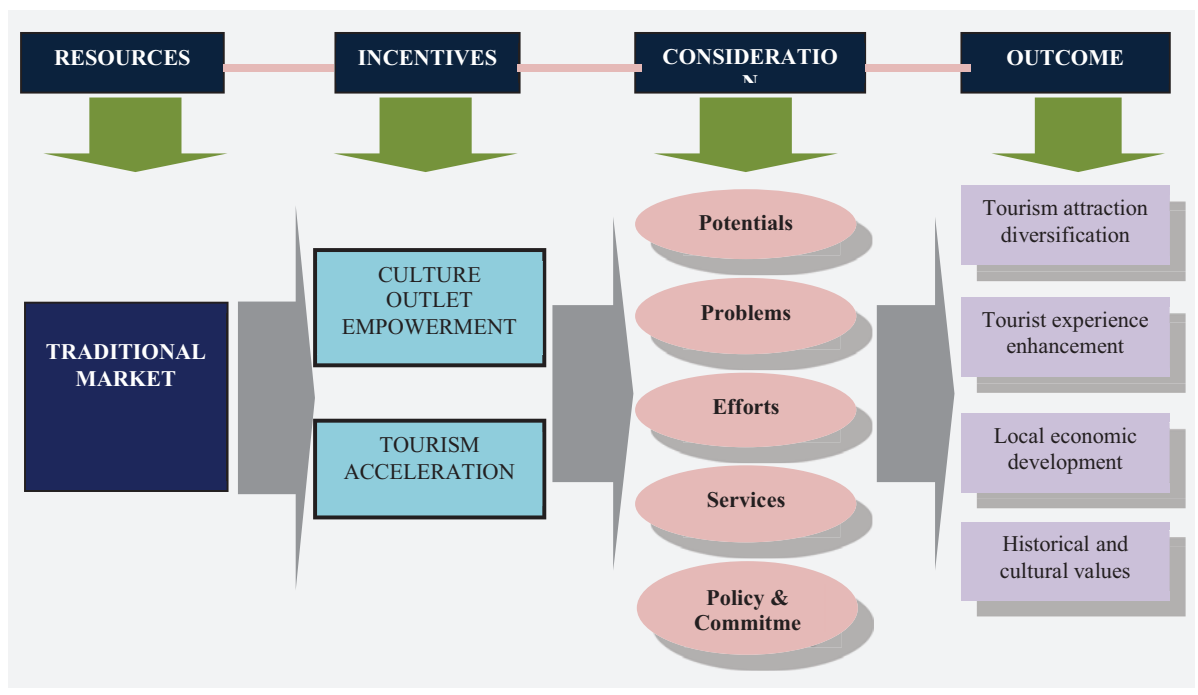

Figure 4. Cultural Outlet and Tourism Acceleration Model (COATAM)

is a key to realize the success of traditional market developmet as cultural outlet product and tourism destination. In general, there are four main components in COATAM model, including resources, incentives, consideration and outcome.

\subsubsection{Resources}

Resources reflect the main resource, namely the traditional market itself, Pasar Klewer. As the main resource, Pasar Klewer has strengths and weaknesses as well as opportunities and challenges for the development in the braod scale, including the development with optimizing market benefit as cultural product outlet and tourism destination. Pasar Klewer has the uniqueness viewed from historical and cultural contexts as well as the image strength as one of the trading centers in Surakarta District, while from its entities, its building has some weaknesses, such as the availability of parking lot. By this uniqueness, Pasar Klewer has an opportunity to become a reliable shopping center since it concerns on users' safety and comfort, for both buyers and sellers.

\subsubsection{Incentives}

Incentives are driven factors or stimulations to achieve the optimal result. In another word, incentives are supporting elements. In COATAM model, incentives consist of culture outlet empowerment and tourism acceleration. Culture outlet empowerment refers to the effort of traditional market empowerment as a cultural product outlet, in which the existence of traditional markets plays an important role in supporting the production of various cultural art products because the creators have their space to communicate their products to buyers. If the traditional market empowerment can be conducted, strengthening traditional market role in supporting the revitalization of culture will be realized. It indicates that the culture outlet empowerment plays supporting factor in the realization of strengthening traditional market role. Hence, traditional markets become generators in realizing the revitalization of local cultures, including cultural products in terms of various crafts. Due to this condition, traditional market development and management needs to notice traditional market characteristics as the basic locations to communicate cultural produts to consumers. Each tradtional market has physical and non-physical characteristics. Physical characteristics refers to physical things, such as location or the existence of building, the shape of building, landmass of bulding, and content of building. Meanwhile, non-physical characteristics deal with non-physical things, such as social and cultural problems. For example, a planner must notice if a developed traditional market is a typical place for surrounded society to shop typical stuffs. Both physical and non-physical characteristics must be taken seriously to become the basis in strengthening traditional market roles as cultural product outlet and tourism attraction. Besides, tourism acceleration deals with a way to accelerate tourism development in Surakarta District, particularly through the utilization of traditional markets as unique tourism attractions. In addition, it functions as supporting optimalization toward traditional market benefit. Moreover, in Surakarta District, toursim development aceleration needs to undeline some aspects, namely the strength of a tourism attraction to bring tourists, opportunity to open business in tourism, opportunity to increase community's income, opportunity to create job opportunity for community, and opportunity to build local economy through strengthening traditional market role as tourism attraction. By utilizing traditional markets as tourism attraction, the synergy between traditional markets and economic development through tourism will be realized.

\subsubsection{Consideration}

The third important component in COATAM model is consideration, referring to the basic consideration in traditional market development as cultural product outlet and tourism destination. Consideration has some elements, namely potentials, problems, efforts, services, policies and commitments. 


\subsubsection{Outcome}

Outcome indicates the result intented to be achieved in the long term from the utilization of traditional markets as cultural product outlets and tourism destination. It consists of tourism interest diversification, tourist experience enhancement, local economic development, and historical and cultural values.

a) Tourism attraction diversification

Tourism attraction diversification refers to the effort to diversify tourism attraction, so tourism destination choices are excessively available of which tourists enjoy to visit. Tradtional markets, particularly Pasar Klewer, become one of tourism location alternatives probably visited by tourists.

b) Tourist experience enhancement

Tourist experience enhancement is the effort to maximize tourist experience while visiting tourist destination. Traditional markets as cultural product outlets are expected to be one of the attractions that can add or increase tourist experieces. Besides, traditional markets play a role in providing various souvenirs as cultural creation results.

c) Local economic development

In COATAM model, local economic development is one of the output targets, in which all efforts of traditional market utilization as cultural product outlet and tourism destination are objected to push community's economy development. Besides, it also indicates that the effort to maintain local resource owned by traditional market (Pasar Klewer) is conducted by underlining the existence of networks, collaborations and partnerships among buyers, local government in terms of market office of Surakarta District, and private sectors in terms of traders/ businesspersons. These aim to provide job opportunities that support the local economic development. The local economic development is also directed to realize the better economic development with finally aiming to increase the life quality of traditional market in general. The effort on optimizing local economic development is a key to contribute to the fast development of traditional markets, including Pasar Klewer. Through this economic development, local community will be freed from underdevelopment and limitation in obtaining opportunities to get a better walfare level of life. However, to achive this, community are required to be independent in taking their effort and working in the traditional market environment. Local resources consist of all strengths and potentials owned by traditional markets, including art and cultural resouces, tourism attraction, human resources, knowledges, experiences, and technologies controlled by traditional market community, as well as abilities and competences in managing those resouces.

d) Historical and cultural values

Historical and cultural values are the basic capitals for the traditional market (Pasar Klewer) to develop itself as the cultural product outlet and tourism destination. Pasar Klewer has the historical value related to the existence of Kraton Surakarta Hadiningrat. Tourists who visit Pasar Klewer can be directed to visit Kraton Surakarta Hadiningrat, and vice versa. Besides, Pasar Klewer is a place that becomes a connector of sellers and buyers, so buyers can enjoy cultural works produced by the community in terms of products sold in the market, including batik and lurik, the adiluhung (great) works of Indonesian people.

\section{Conclusions}

Based on studies conducted by some researchers, there are some important points needed to be pointed out. In relation to the existence of Traditional Markets in City Center, as studies conducted by Pamardhi (1997), Abdullah (2006), and Sunoko (2002) on various functions of traditional markets, Hayami (1987) on the role of traditional market, Alexander (1987) about the impact of economy on traditional markets, and Karnajaya (2002) about the impact of traditional market location in a city, this study emphasizes that the existence of traditional markets plays a role as urban structure components as well as populistbased trade facilities, and interaction spaces for market actors as well as cultural product displays of the local communities. It is in line with some studies conducted by Pamardhi (1997), Abdullah (2006), and Sunoko (2002).

In regard with the scope of traditional market service, the study refers to the empirical data and results suggested by Aliyah et al. (2017b), Alexander (1987), Karnajaya (2002) and Andriani and Ali (2013). Based on the ratio of the number of traditional markets with the area served, there is an overlapping service scope with reference to the analysis result of the distribution pattern and the number of traditional markets. However, the empirical data shows that there is no interest of consumers in the scope of services. It is due to that each traditional market has different commodity and market segment.

Meanwhile, traditional markets in Asian countries are located in rural and urban areas (Aliyah et al., 2017a). While traditional markets in Surakarta District are located in the city center with varied roles and functions, and build the constellation toward other urban structure components, namely mosque, kraton or government center. Traditional markets have strategical roles in maintaining the structures of development centre, and are able to generate economic activities surrounding the markets (Alexander, 1987). Besides, market relocation is also able to change land use and even distribution of circulation line (Karnajaya, 2002). Moreover, the existence of traditional markets is related to social capitals in terms of norms, belief, and bargaining that can strengthen loyal networks of market visitors to keep shopping in traditional markets (Andriani \& Ali, 2013).

The result related to the role of traditional markets as cultural product outlets shows that traditional markets are one of the tourism destinations that have historical values as community cultural product outlets and populist economic spaces based on human resource abilities. The diversity of activities in traditional markets will stimulate other supporting activities, and will create continues developing space function, followed by the development of trade, transportation, goods and services procurement, or 
combination of those activities (Aliyah et al., 2017a). This is supported by Rahadi who investigated consumers' and sellers' service characteristics in the aspatial context on traditional markets (Rahadi, 2012). It is emphasized by Andriani and Ali that the existence of traditional markets is inseparable from social capitals (Andriani \& Ali, 2013).

In connection to the role of traditional market as tourism destination in the current era, traditional markets start to conduct improvements by providing cleaner and comfortable facilities and goods. Surakarta Trade Service states that market revitalization keep being conducted to attract society interest and to give optimal services to visitors, both traders and tourists. It is similar to Dragicevic and Tevsic (2015) who said that a continuous expansion of marketing activities and the implementation new marketing strategies in embodied business practice of culture are needed (Dragicevic \& Tevsic, 2015).

As an effort to create Traditional Markets as Cultural Outlet Products and Tourism Destinations in the Current Era, the formulation of traditional market model is used as the basic concept for traditional market development and structure. Based on the investigation on the growth of traders and consumers in terms of buyers and distributors; physical and non-physical condition; as well as safety and comfort in activities and transactions, a continues innovation is needed to fulfil consumers' need with various and smart demands. This has to be done by three organization capacities including Connect, Energize, and Refresh (Sipe, 2016). Moreover, service orientation and work atmosphere become an effective mediator from market actors in traditional markets. It is in line with $\mathrm{Li}$ and Huang (2017). Meanwhile, customer satisfaction is affected by service failure. To effectively recover the service due to failure is conducted by 1) immediately correcting the problem, 2) asking for forgiveness, 3) compensation, and 4) discount (Wu et al., 2018). Regarding this result, Culture Outlet and Tourism Acceleration Model abbreviated as COATAM is formulated.

Henceforth, the interrelationship of some aspects in Urban Planning theory can be wholy formulated in the spatial, aspatial, social and cultural aspects to become interrelated unified chain. The result of this study become part of Urban Planning theory with focusing on traditional market development as one of the urban facilities from the spatial aspect. The use of this study is directly received by market actors, policy makers of Surakarta government, communities and tourists, as well as academians in scientific development related to the development of art-culture and populist tourism based on populist economy.

\section{Acknowledgments}

The research team say thanks to Universitas Sebelas Maret that gives its support through the Hibah Penelitian Unggulan Terapan PNBP (Competitive Grant Research), Universitas Sebelas Maret with contract number: 516/ UN27.21/PP/2019.

\section{References}

Abdullah, I. (2006). Konstruksi dan reproduksi kebudayaan [Cultural construction and reproduction]. Pustaka Pelajar.

Alexander, J. (1987). Trade, trades and trading in rural Java. Oxford University Press.

Aliyah, I., Daryanto, T. J., \& Rahayu, M. J. (2007). Peran pasar tradisional dalam mendukung pengembangan pariwisata kota Surakarta [Role of traditional market in supporting tourism development in Surakarta district]. Gema Teknik, 2, 111-118. http://puslit2.petra.ac.id/ejournal/index.php/gem/article/ view/17613

Aliyah, I., Setioko, B., \& Pradoto, W. (2016). The roles of traditional markets as the main component of Javanese culture urban space (Case study: the city of Surakarta, Indonesia). The IAFOR Journal of Sustainability, Energy \& the Environment, 3(1), 103-120. https://doi.org/10.22492/ijsee.3.1.06

Aliyah, I., Setioko, B., \& Pradoto, W. (2017a). Spatial variety and distribution of traditional markets in Surakarta as potential factors in improving spatial-based management. Journal of Geomatics and Planning, 4(1), 63-74.

https://doi.org/10.14710/geoplanning.4.1.63-74

Aliyah, I., Setioko, B., \& Pradoto, W. (2017b). Spatial flexibility in cultural mapping of traditional market area in Surakarta (A case study of Pasar Gede in Surakarta). City, Culture and Society, 10, 41-51. https://doi.org/10.1016/j.ccs.2017.05.004

Andriani, M. N., \& Ali, M. M. (2013). Kajian eksistensi pasar tradisional kota Surakarta [Study on traditional market existence in Surakarta district]. Jurnal Teknik PWK Universitas Diponegoro, 2(2), 252-269.

Bromley, R. (1987). Traditional and modern change in the growt of systems of market centres in highland Equador. The Centre for Transportasion Studies.

Dragicevic, M., \& Tevsic, A. (2015). Traditional cultural manifestation marketing and service. Procedia Economics and Finance, 433-436.

Duxbury, N., Garrett-Petts, W. F., \& MacLennan, D. (2015). Cultural mapping as cultural inquiry: Introduction to an emerging field of practice. Routledge.

https://doi.org/10.4324/9781315743066

Ekomadyo, A. S. (2007). Menelusuri Genius Loci pasar tradisional sebagai ruang sosial urban di nusantara [Searching Genius Loci of traditional market as urban social space in Indonesian archipelago]. http://www.ar.itb.ac.id/pa/wp-content/upload/2007/11/201212

Freitas, R. (2016). Cultural mapping as a development tool. City, Culture and Society Journal, 7, 9-16. https://doi.org/10.1016/j.ccs.2015.10.002

Hayami, Y. (1987). Dilema desa [Village dilemma]. Yayasan Obor.

Javalgia, R. R. G., \& Grossman, D. A. (2016). Aspirations and entrepreneurial motivations of middle-class consumers in emerging markets: The case of India. International Business Review, 25(3), 657-667. https://doi.org/10.1016/j.ibusrev.2015.10.008

Karnajaya, S. (2002). Pengaruh pemindahan lokasi pasar terhadap morfologi kota Semarang [The role of market relocation toward morphology of Semarang district]. Graduate School, Universitas Diponegoro.

Kim, J. I., Lee, C. M., \& Ahn, K. H. (2004). Dongdaemun, a traditional market place wearing a modern suit: the importance of the social fabric in physical redevelopments. Habitat International, 28(1), 143-161. https://doi.org/10.1016/S0197-3975(03)00036-5 
Kota Surakarta. (2018, March 22). Pasar Klewer Solo - sejarah dan perjalanan panjangnya hingga kini. https://www.surakarta.pro/pasar-klewer/

Li, Y., \& Huang, S. S. (2017). Hospitality service climate, employee service orientation, career aspiration and performance: A moderated mediation model. International Journal of Hospitality Management, 67, 24-32. https://doi.org/10.1016/j.ijhm.2017.07.012

Ma, Z., Li, C., Liu, Y., \& Zhang, J. (2018). The transformation of traditional commercial blocks in China: Characteristics and mechanisms of youthification. City, Culture and Society, 14, 56-63. https://doi.org/10.1016/j.ccs.2018.02.001

Miles, M. B., \& Huberman, A. M. (1994). Qualitative data analysis: an expanded sourcebook. Sage Publications.

NÆss, P., \& Jensen, O. B. (2004). Urban structure matters, even in a small town. Journal Environmental Planning and Management, 47(1), 35-37. https://doi.org/10.1080/0964056042000189790

Pamardhi, R. (1997). Planing for traditional Javanese markets in Yogyakarta region. University of Sydney.

Putra, R. D., \& Rudito, B. (2014). Planning community development program of Limbangan traditional market revitalization with social mapping. Procedia - Social and Behavioral Sciences, 169, 143-150. https://doi.org/10.1016/j.sbspro.2015.01.296

Pillai, J. (2013). Cultural mapping: a guide to understanding place, community and continuity. Strategic Information and Research Development Centre Publishers.

Rahadi, R. A. (2012). Factors related to repeat consumption behaviour: a case study in traditional market in Bandung and
Surrounding region. Procedia - Social and Behavioral Sciences, 36, 529-539. https://doi.org/10.1016/j.sbspro.2012.03.058

Sipe, L. J. (2016). How do senior managers influence experience innovation? Insights from a hospitality marketplace. International Journal of Hospitality Management, 54, 75-83. https://doi.org/10.1016/j.ijhm.2016.01.009

Sirait, T. S. (2006). Identifikasi karakteristik pasar tradisional yang menyebabkan kemacetan lalu-lintas di kota Semarang [Identification of traditional market characteristic affecting traffic congestion in Semarang district]. Department of Regional and City Planning.

Sunoko, K. (2002). Perkembangan tata ruang pasar tradisional: kasus kajian pasar-pasar tradisional di Bantul [Development of traditional market spatial planning: case study of traditional markets in Bantul]. Faculty of Engineering, Universitas Gadjah Mada.

Wheelen, T. L., \& Hunger, J. D. (2012). Strategic management and business policy: toward global sustainability (13 ed.). Pearson Education, Inc.

Wongleedee, K. (2015, July 25). Marketing mix and purchasing behavior for community products at traditional markets. Procedia - Social and Behavioral Sciences, 197, 2080-2085. https://doi.org/10.1016/j.sbspro.2015.07.323

Wu, W. Y., Qomariyah, A., Sa, T. T., \& Liao, Y. (2018). The integration between service value and service recovery in the hospitality industry: an application of QFD and ANP. International Journal of Hospitality Management, 75, 48-57. https://doi.org/10.1016/j.ijhm.2018.03.010 